\title{
Cambridge Meeting of the British Association
}

\section{Sectional Programmes}

\section{Section A (Mathematical and Physical Sciences)}

7 HE programme of Section $A$, as seems appro. priate at Cambridge, is less concerned with applied physics than has been the case for a year or two. The opening morning is devoted to a symposium on nuclear physics, in which Niels Bohr and W. Bothe will represent the Continental workers. On Friday, after the presidential address, the Section will divide into two, one part discussing the fundamentals of magnetic theory and the other hearing three papers on subjects of astronomical interest. The first, by Shapley, is on the galaxy, the second is by Ives, and deals with his recent experiments in which the theory of special relativity receives direct support from experiments on the light emitted by positive rays, and the third is an account by $R$. W. Wood of the new diffraction gratings, which have so improved the technique of astrophysical work with spectrographs. The Saturday morning will find the Section at work on problems of cosmic rays, with an American and a German guest, in the persons of Prof. Furry and Prof. E. Regener. In the second week come symposia on low temperature (particularly that queer material, liquid helium II), and on seismology, the latter taking place at the same time as a further discussion on magnetism, this time jointly with Section G (Engineering).

Those who have missed the general excursions by attendance at the meeting on Saturday will find consolation in the fact that the Section dinner, to be held for the first time, is booked for that evening ; they may fill in the afternoon at a garden party in the Observatory. Other visits during the week are to the works of the Cambridge Instrument Co., Ltd., and to the Cavendish and Mond laboratories, where a film of solar prominences will be shown, and a record of the voice of the late Lord Rutherford will be heard.

ThE Department of Mathematics has a programme which is exceptionally attractive mathematically. Among the visitors expected are Prof. G. D. Birkhoff, Prof. S. Lefschetz, who will lecture on the fundamental problem of fixed points in topological transformations, Prof. A. Ostrowski, bringing a modification of Newtonian approximation, and Prof. A. Speiser, looking at elliptic functions from the point of view of elementary geometry. The theory of groups and topological algebra are represented further by Mr. P. Hall, Dr. B. H. Neumann, Dr. O. Taussky and Mr. J. H. C. Whitehead, as well as by Mr. M. H. A. Newman, who is to speak on the topological characterization of the sphere in $n$ dimensions, a problem which goes back to Poincaré. Prof. W. V. D. Hodge and Mr. B. Kaufmann have contributions on geometry and analysis, and Prof. E. H. Neville and Mr. D. H. Sadler will follow Prof. Ostrowski.

The Association's Committee on the Calculation of Mathematical Tables, acting through Dr. W. G. Bickley, Dr. J. C. P. Miller and Dr. A. J. Thompson, will take members behind the scenes to look at some of the problems, mathematical and typographical, that come between the simple decision to tabulate a function and the appearance of the printed volume. The National Accounting machine used by the Committee for sub-tabulation and the preparation of printers' copy is to be brought from London for inspection and demonstration, with an operator to explain the adaptations and ingenuities which have effected its conversion from commerce to pure science. Explanations and demonstrations will be given also of a number of other machines, including a model of the Bush integrator, the Mallock equation-solver and Hollerith and other machines ; in this exhibition the companies concermed are co-operating with the Association. Interest in the practical side of computation has been expressed and stimulated at Cambridge by the establishment of a mathematical laboratory, and a visit is planned to this embryonic institution.

Lastly, the application of methods and ideas of combinatorial analysis to the planning of biological experiments will be explained in a series of papers by Dr. C. C. Craig, Mr. H. W. Norton, Mr. W. L. Stevens, Mr. F. Yates and Dr. W. J. Youden.

\section{Sectron B (Chemistre)}

The president, Prof. C. S. Gibson, in his opening address, will review the recent advances that have been made, chiefly by himself and his co-workers, in the chemistry of gold. This will be followed by a discussion on the recent advances in the organic chemistry of the metals with special reference to the noble metals, in which the principal speakers will be Dr. F. G. Mann, Prof. L. O. Brockway (Pasadena) and Prof. N. V. Sidgwick. Attention will be directed mainly to the electronic and stereochemical aspects of the subject. In the afternoon, Prof. Gibson, with the assistance of Dr. F. G. Mann, Mr. H. V. Thompson and Dr. F. H. Brain will give a demonstration on the production and application of gold films by ancient and modern methods. The processes employed in the ceramic industry and methods depending on the decomposition of organic compounds of gold will be demonstrated. Many specimens will be on exhibition. The demonstration is arranged to be of general rather than purely sectional interest.

A discussion on modern methods of chemical analysis, including physical and microchemical methods, will be opened by Dr. J. J. Fox, Govern. ment Chemist. Contributions will be made by Prof. Walther Gerlach (Munich), Prof. Fritz Feigl, Dr. Janet Matthews, Dr. H. Jackson and Dr. K. K. Nygaard (Oslo).

Prof. W. L. Bragg will open a discussion on "Clays". $\mathrm{He}$ will be followed by Dr. R. K. Schofield, Dr. Nagelschmidt and Prof. J. D. Bernal. The speakers will deal with the atomic architecture of clay and clay-like minerals, with the origin of the electric charges on clay particles, with base exchange, the absorption and yielding up of water and the behaviour of clays in soils.

The fourth symposium of the meeting, entitled "Repercussions of Synthetic Organic Chemistry on Biology and Medicine", which has an added interest 
in view of the exceptional circumstance that the Physiological Section will not meet this year, is being arranged by Prof. E. C. Dodds and Prof. J. W. Cook. Recent work on the production of new compounds having the biological action of the sex hormones will be described by Prof. Dodds and Prof. L. Ruzicka (Zurich), and Dr. A. S. Parkes will deal with some of their interesting biological interrelationships. The second half of the programme will be occupied with descriptions of synthetic compounds which are able to induce cancer (Prof. J. W. Cook), of new compounds having the physiological action of the lifemaintenance hormone of the adrenal cortex (Dr. T. Reichstein, Zurich), and of the synthesis of vitamin $B_{1}$ and analogous compounds (Prof. A. R. Todd). Specimens and apparatus relating to these discussions will be on exhibition throughout the meeting.

By the kind invitation of Sir William Pope, a visit will be made to the University Chemical Laboratories. Sir F. Gowland Hopkins has also kindly invited the Section to visit the Departments of Biochemistry and Parasitology. Visits will be made to the Cambridge Instrument Co., Ltd., and Messrs. Stewarts and Lloyds' steel works at Corby.

The sectional dinner will be held in Sidney Sussex College, by kind permission of the master and fellows. The following chemists have accepted the Council's invitation to attend as foreign guests of the Association : Prof. G. Bertrand, Paris; Prof. L. O. Brockway, Pasadena; Prof. Fritz Feigl; Prof. Walther Gerlach, Munich; Dr. T. Reichstein, Zurich; and Prof. L. Ruzicka, Zurich.

\section{Section C (Geology)}

Up to the delivery of Prof. H. H. Swinnerton's address on "Development and Evolution", the interest of the programme of Section C is mainly on the stratigraphical and palæontological side. After the address the petrological side dominates.

The post-glacial history of the Fenlands is to be considered jointly with Section $K$ (Botany). Short papers dealing with levels and benchmarks, archæological correlations, conditions in Roman times, and the Foraminifera in the deposits, will provide the basis around which the discussion can range.

A more specialized subject is "The Distribution and Migration of Certain Animal Groups in the British Lower Palæozoic Fauna". Dr. C. J. Stubblefield will open and deal with the Trilobites, and Dr. G. L. Elles on Graptolites, Dr. W. K. Spencer on Starfishes and Dr. A. Lamont on Brachiopods will follow. With such experts on these particular groups, important points in palæogeography may emerge.

The association and origin of alkali-rich igneous rocks with limestones has long been of considerable petrogenetic significance. This time the question is to be debated from the opposite angle: "The Origin of the Carbonate Rocks associated with Alkali-Rich Intrusions". Dr. H. von Eckermann of Sweden will open the discussion.

Water supply matters are very much to the fore at the present time. Dr. J. Buchan, in dealing with the underground supplies of London, will show that the progressive lowering of the water-level there is giving rise to concerm about the life of the supply. This lowering, also, is leading to a deterioration in quality due to the drawing in of contaminated surface waters.

Among the papers to be given, those concerning some peculiar leucite rocks from Australia, the granites of the Egyptian desert, the palisade diabase sill of New Jersey, and the occurrence of zonal olivines should be of considerable interest.

\section{Section D (Zoology)}

Section D (Zoology) will be presided over by Dr. S. W. Kemp, whose presidential address will deal with the future of oceanography.

The item in the programme of the Section which will perhaps arouse the most general interest is a discussion on the mechanism of evolution, extending over a whole day. The range of the discussion will cover such aspects of the subject as the importance of character gradients, selection, orthogenesis, consequential evolution, polymorphism and isolation as factors in the evolutionary process. The speakers include Prof. J. S. Huxley, Prof. R. A. Fisher and Prof. A. E. Trueman.

Prof. J. Gray will introduce a discussion on the role of the environment in animal locomotion, and the papers which follow will treat mainly of the work of the Cambridge school in the analysis of locomotion in aquatic, terrestrial and aerial forms of life. A symposium on sense perception and the evolution of colour and pattern will be introduced by Prof. J. S. Huxley, and contributions from Dr. H. B. Cott, Mr. D. Lack and Mr. I. Burkill will treat of the subject from the point of view of protective coloration, the courtship of birds, and the correlation between insect vision and flower colour respectively.

Dr. H. C. Gilson is to give a semi-popular lecture on the recent expedition to Lake Titicaca.

There will again be an exhibition of biological films of educational interest. These will include two films, produced by the Strand Film Co., Ltd., on mites and monsters and monkey to man, shown by Prof. J. S. Huxley, and films, produced by Gaumont British Instructional Films Co., Ltd., on the liverfluke, the crayfish, and the development of the trout, shown by Mr. H. R. Hewer. An excursion to Wicken Fen and Breckland is included in the programme of the Section for the Saturday of the meeting.

\section{Section E (Geography)}

The programme for Section $E$ will be opened by the president, Prof. Griffith Taylor, who proposes to deal with geography as an aid to social problems, history and race. His address will be followed by a number of short papers and a film dealing with the impressions of geographers during the recent visit of the Association to India.

On Friday there will be a series of local papers, including two lectures preparatory to the excursions on Saturday and Sunday. Of these latter the first will be to the north Norfolk coast, while the second will visit the Fens. Monday is to be given over largely to a consideration of the physical factors affecting English ports and estuaries and will include a visit to the Great Ouse Catchment Board.

On Tuesday morning a sectional discussion on "Some Aspects of the Regional Concept" will be opened by Dr. S. W. Wooldridge, while in the afternoon two papers will discuss some particular features of population distribution. On the last morning Dr. Vaughan Cornish will continue his plea for the preservation of coastal scenery, this time at Sidmouth, and Brigadier Macleod will discuss the Departmental report on the Ordnance Survey. 
Among individual contributions not already mentioned may be instanced a discussion on the geographical laboratory, to be opened by Prof. F. Debenham, an account of some of the discoveries of the recent Graham Land expedition by Mr. Bertram, and some further results of his work on cirque formation by $\mathrm{Mr}$. W. V. Lewis. The programme includes a much larger number of short papers than usual, and by reason of its wide field should offer many items of interest to members of other sections.

\section{Section F (ECONomics)}

The programme of Section $F$ is very largely given up to the discussion of current matters of public importance, and with the development of statistical and other methods for investigating them.

There will be three papers by Sir William Beveridge, Mr. D. Champernowne and Mr. R. C. Tress on various aspects of unemployment in relation to the trade cycle; its connexion with the local diversity of industry, and its recent trends. The statistical methods of testing trade cycle theories and of measuring the mobility of labour are being discussed by Prof. Tinbergen and Dr. Marschak of the Institute of Statistics, Oxford, respectively. Other topics of current importance under discussion will be public works policy in the trade cycle, the economics of road haulage since the Road and Rail Traffic Act of 1933, and the economic recovery of Germany. Mr. J. M. Keynes has promised a paper on "The Problem of Government Storage of Food Stuffs and Raw Materials".

Mr. R. F. Harrod, the president, is speaking on "The Scope and Method of Economics", a topic which should be of interest in relation to contemporary developments and controversy. The Section has also made arrangements for a discussion of papers on general sociological questions, by Mr. T. H. Marshall on "Professionalism" and Prof. M. Ginsberg on "The Present Position of Sociology".

\section{Section G (ENGINEERING)}

In his presidential address Prof. R. V. Southwell will deal with the "Changing Outlook of Engineering Science".

There will be a group of papers on problems of vibration, opened by a short paper and demonstration given by Prof. C. E. Inglis. There will be another group of papers dealing with problems in connexion with magnet steels. Major Cook, chief engineer of the Ministry of Transport, will open a discussion with an important paper on the design of roads.

An innovation of great interest is the experiment of including ten short papers by junior engineers who will describe work with which they are intimately connected. Each paper and its discussion will occupy no more than thirty minutes. The meeting will conclude with a lecture and demonstration of engineering instruments given by Mr. Mason of the Cambridge Instrument Co., Ltd.

\section{Section H (ANThropology)}

The anthropological programme is unusually full, and it has been necessary to arrange several parallel series of lectures. On Thursday morning there will be a general discussion on the Australian aborigines, and a film, recently taken by Dr. Donald F. Thomson, will be shown in the new Arts Theatre. In the after- noon, papers will be read on local archæology, in preparation for the excursions on the Saturday and Sunday.

Friday is given up to two symposia; the topic for the morning meetings is the Swanscombe skull, and for the afternoon, the Middle Palæolithic. In both symposia papers will be read on the geology, skeletal remains and human artefacts. The presidential address will be given on Monday morning by Prof. V. Gordon Childe, and Miss Caton Thompson and Miss Gardner will describe the results of their recent expedition to South Arabia. In the afternoon Sir Arthur Keith will speak on the Mount Carmel skeletons, and on a reconsideration of the Piltdown skull. Other papers will also be given on Cypriote skulls, the stability of English rural population, and on natural selection.

There will be a number of papers on folk-culture on Tuesday morning, and in the afternoon four papers on ritual-ritual and emotion, ritual and tradition, ritual and myth, and ritual and magic. General ethnology will also be represented by a number of contributions on Cambridge, Lapland, West Africa, and Zanzibar, and by papers on boats, primitive art, currency, and on sign language.

\section{Section I (Physiology)}

The International Physiological Congress is being held at Zurich on August 14-19; it has therefore been decided not to hold meetings of Section $I$ at Cambridge.

\section{Section J (Psychology)}

Section $J$ (Psychology) has a very full programme. The presidential address, to be delivered by Dr. R. H. Thouless, is entitled, "Eye and Brain as Factors in Visual Perception".

Roughly grouping the other topics, there are papers on social psychology covering the social implications of vocational guidance, friendliness and unfriendliness between different social groups, generalized foreign politics (this last a mathematical analysis) and problems of the social psychology of childhood. General psychology is being dealt with in papers on present trends in American psychology and on hormic psychology, while merging into things therapeutic, we get problems of the mature personality, the back. ground of the problem child, the teaching of mental hygiene through literature, with a turn towards heredity in papers on heredity and mental hygiene and the inheritance of temperament respectively.

Dealing more with the experimental side, are papers on motor learning and the morphology of responses, the direction of thought, a curious pitfall in factor psychology, verbal problems connected with the definition of personal qualities, factors affecting the reliability of interviews, behaviour when attempt. ing difficult tasks, sensory adaptation (in vision and hearing) and colour blindness. Animal psychology is represented by a paper on recent experiments with birds, while there is a joint session with Section $\mathrm{L}$ (Educational Science) on the influence of wireless and the cinema on education.

\section{Section K (Botany)}

The botanists and foresters who gather at Cam. bridge may anticipate an interesting meeting, for a full programme is in prospect. The president, 
Prof. W.Stiles, willopen the proceedings with his address on the general physiology of the plant cell. This will be followed by the address of the chairman of Department K*, Sir Roy Robinson, who will speak on the supply of home-grown timber.

A number of joint meetings have been arranged. Sections $C$ and $K$ will unite in a meeting on the postglacial history of Fenland, in which botanical, geological and archæological matters will be discussed. A meeting of Sections $D$ and $K$, spread over two sessions, will be concerned with the mechanism of evolution, a subject which should provide abundant argument both formal and informal. Botanists and foresters will consider together the relation of ecology and forestry.

A group of contributions on the virus diseases of plants, followed by a discussion, will indicate the present position of this important branch of plant pathology.

In addition to the selected subjects which have been mentioned, many separate communications will be presented. These include series of papers on plant physiology, mycology and palæo-botany, and others on genetics, morphology and ecology.

The foresters (Department $\mathrm{K}^{*}$ ), in their separate meetings, will devote three sessions to a consideration of the cultivation and utilization of British hardwoods, and a further session to soil problems and to pathology.

Prof. A. H. R. Buller will deliver the semi-popular lecture; he will speak on sex in the rust fungi.

An extensive display of exhibits will illustrate many aspects of botany. It is expected that much of the material will be on view during most of the week, and, during one afternoon session, exhibitors will give demonstrations and explanations.

Excursions to places of interest to botanists and foresters will take place during the meeting, the principal excursions falling on Saturday and Sunday.

\section{Section L (Educational Science)}

The greater part of the Section's programme, as in recent years, will be devoted to one or two main subjects ; the principal theme for 1938 is "Education for a Changing Society". The speakers on this theme will examine to what extent the education given in the senior, secondary and technical schools aims at preparing their pupils to meet the complex needs of the rapidly changing world of to-day. Miss Dawson of Middlesbrough and Mr. Robinson of Sheffield will speak as heads of senior schools, while Miss Davis of Streatham and Dr. Freeman of Winchester will discuss the contribution of secondary schools. Mr. Paley Yorke of Poplar, Dr. Richardson of Derby and Mr. Frank Pick of the London Passenger Transport Board will analyse the part played by technical education, and Dr. Winifred Cullis will represent the point of view of the universities.

Another outstanding item will be a symposium on Thursday on "Tendencies in School Design", when papers will be read by Mr. S. Urwin of Cambridge, Mr. Denis Clarke-Hall and Mr. W. G. Newton of London and Mr. W. D. Seymour. (In connexion with this subject there will be an exhibition of school models and designs by courtesy of the Royal Institute of British Architects.) A joint session will be held with Section J (Psychology) on the influence of films and wireless on the education of the school child,
Mr. R. C. Steele, of the B.B.C., and Dr. P. B. Ballard speaking for Section $\mathrm{L}$.

The president, Mr. J. Sargent, director of education for Essex, will deliver his presidential address on Friday, taking as his subject the "Function of the Administrator". The interim report of the Research Committee on the Informative Content of the Curriculum will be presented at the same session by Mr. H. G. Wells and Sir Richard Gregory.

\section{Section M (Agriculture)}

The general theme for all the paper-reading sessions of Section M is "Agriculture in Relation to the Life of the Community". On the Thursday morning there will be a symposium on "Agriculture in Relation to National Employment". Prof. C. S. Orwin will open this and will deal in general with the demands for labour in agriculture. He will be followed by Prof. Scott Watson, who will consider the influence of systems of farming on labour requirements ; by $\mathrm{Mr}$. S. J. Wright, who will speak on "Men and Machines", (including transport on the farm); and by Dr. F. Kidd, who will deal with the "Preservation, Storage and Transport of Farm Produce". There will be a general discussion opened by Prof. R. G. White.

On Friday morning, Prof. R. G. Stapledon will give his presidential address, entitled "Lay Farming and a Long Term Agricultural Policy". This will be followed by two papers on soil problems, namely, "Problems of Marginal and Waste Land" by Dr. W. G. Orr, and "The Maintenance of Soil Fertility" by Dr. E. M. Crowther. The general discussion will be opened by Sir Daniel Hall.

Monday morning will be devoted to a consideration of "The Practical Problems of Crop Production", in which Mr. J. A. McMillan will deal with crop husbandry, Prof. F. L. Engledow with the place of plant physiology and of plant breeding in the advancement of British agriculture, and Mr. C. T. Gimingham with crop pests and disease. Sir John Russell will open the general discussion which follows.

On Tuesday morning there will be a symposium on "The Practical Problems of Animal Production". Prof. R. Rae will open this with a paper on animal husbandry. He will be followed by Prof. F. A. E. Crew, who will speak on animal breeding, and by Dr. E. L. Taylor, who will deal with parasitic diseases in animals.

\section{Conference of Delegates}

The Conference of Delegates of Corresponding Societies will be presided over by the Right Hon. the Earl of Onslow, and among the principal subjects to be considered are some of wide and national importance. Lord Onslow in his address will deal with "The Importance of National Parks in the Preservation of the Flora and Fauna of Great Britain", while the urgent desirability of the preservation of Crown lands will be especially referred to by Dr. Vaughan Comish.

Another subject of more than local interest is that of Wicken Fen and what the National Trust has done for East Anglia, upon which Mr. N. B. Kinnear and Dr. M. F. Valentine will speak.

The problem of obtaining periodical and simultaneous field observations over wide areas upon such matters as bird and insect migrations, the prevalence and distribution of wild plant and animal communities 
both harmful and beneficial, and the effects upon these of the widespread planning and industrial development of recent years is becoming a matter of significant importance in biological studies; and the co-operation of the corresponding societies in the study of systematics in relation to general biology, which will be discussed in a communication from Mr. H. W. Parker, should prove of assistance and value in effectively ascertaining the desired information by co-ordinated field observations upon specific subjects.
An innovation will this year be introduced at Cambridge when the delegates of the corresponding societies and their guests will dine together, Lord Onslow presiding. They will also attend an aftermoon garden party at the Cambridge Botanic Gardens as the guests of Prof. F. T. Brooks. The view has been expressed that the business of the Conference affords insufficient opportunity for that social contact which is considered desirable and can best be attained by such functions.

\section{National Efforts in Cancer Treatment}

$\mathrm{T}$ HE eighth annual reports of the National Radium Trust and Radium Commission, 1936-1937 (published in December 1937)* is of special interest in that it breaks away from the immediate task which confronted it in 1929 and now seeks to guide activities on a broader basis. The following paragraph, taken from p. 23, illustrates this :

"The Commission believes that to secure a reason. able standard of service for the treatment of cancer cases throughout the country there is need for the whole problem to be attacked by the Government along national lines. This belief is supported by the fact that only a proportion of patients suffering from cancer in sites suitable for treatment by radio. therapy are receiving that treatment".

With the resources initially placed at the disposal of the Trust and the Commission, it was decided that a practical beginning to the problem of using radium in the treatment of disease could best be obtained in the way the Commission strove, namely, to secure so far as possible the concentration of radium treat. ment at the large voluntary hospitals which provide teaching facilities. It was inevitable that this left large parts of the country unprovided with radium facilities, and in consequence centres other than the national centres were set up, so that a glance at the map provided on p. 2 of this report shows 13 national centres, 9 regional centres and one recognized hospital where the Commission has its immediate interests.

In the report for the preceding year, the National Radium Trust, in looking to future needs, stated that "The views of the Radium Commission as to the need for further considerable supplies of radium have received and are receiving anxious consideration, the more so as it seems clear that with the trend towards the use of larger units the ultimate need over the next few years will be far beyond the financial resources of the Trust". The Commission now sees this whole problem of the radiological treatment of cancer looming larger with each succeeding year.

This may occasion little surprise to those who have witnessed at close range the developments of radiological treatment, especially in cancer; but it may well be different for those who, with the constant reminder of cancer statistics in front of them, may question how valid is the warrant for any big extension of these services. The fact is that surgical and radiological methods of treatment are the only two methods which are practised on any scale in Great Britain, and with a death-rate not far short of 60,000 people yearly, it is really an urgent matter to make the most of what we have got.

* Eighth Annual Reports of the National Radium Trust and Radium Commission 1936-1937, including a Statistical Report. (Cmd. 5612.) Pp. 80. (London: H.M. Stationery Office.) 18. 3d. net.
Thirty years ago it was not unusual for people to exclaim as to how gladly money would be given for a cure for cancer. It has not been claimed in any one of the reports which have been issued from the Radium Commission that radium treatment is a cure for cancer, but it is claimed, and supported by the most carefully gleaned (not selected) statistics, that large numbers of cancer patients have been treated with radium and have successfully survived periods of five years. Since cancer is likely to recur in the body it is generally held to be unwise to use the term 'cure', but 'freedom from the disease' is a term which is accepted on a clinical basis, and the 'survival rate' is one which is of the first importance in adjudg. ing the value of any remedial measure.

To return to the belief expressed by the Com. mission that the treatment of cancer is a problem to be attacked by the Government. This is shared by many people, but the steps by which it could be carried out have never been laid down, and are but hinted at in the report in question. The Commission does, however, state that an increase of bed accom. modation at or in association with the existing national centres will be required. The words "at or in association with" suggest, and are probably intended to convey, that any such scheme could only be carried out with the active co-operation, possibly the direction, of the Ministry of Health. It is, in fact, very difficult to see, with the pressure upon the bed accommodation of voluntary hospitals all over Great Britain, how any large increase in treatment facilities could occur without very extensive building and staffing. The position is indeed one which calls for the most sympathetic consideration by the Ministry, because by far the greater proportion of radium therapy carried out at present is done at the voluntary hospitals, the part played by those under the direction of the Ministry being, in fact, relatively small, though doubtless locally very important. If, then, the best that we can offer in the way of treat. ment for cancer can only be shared by the whole country by the operation of some comprehensive scheme such as that outlined by the Commission, it is a plain duty to be undertaken.

It has been pointed out more than once that the first need of the population is to be fed, the second is to be housed, the third (perhaps) is to be educated. Then comes the question of fitness in health, and unfitness through ill-health. It may well be that the claims of the treatment of people suffering from cancer may be dislodged from the official mind by the claims of the really healthy, that money should first be spent on the attainment of physical fitness rather than on the relief of the sick.
S. Russ. 